\title{
Phylogeography of the intertidal goby Chaenogobius annularis associated with paleoenvironmental changes around the Japanese Archipelago
}

\author{
S. Hirase ${ }^{*}$, M. Ikeda, M. Kanno, A. Kijima \\ Integrative Aquatic Biology, Graduate School of Agricultural Science, Tohoku University, Tsutsumidori-Amamiya 1-1, \\ Sendai, Aoba, Miyagi 981-8555, Japan
}

\begin{abstract}
We examined the phylogeography of the common Japanese intertidal goby Chaenogobius annularis using the mitochondrial cytochrome $b$ gene, the NADH dehydrogenase subunit 2 gene, and the surrounding transfer RNA from 195 specimens collected in 27 localities around the Japanese Archipelago and the Korean Peninsula, and reconstructed the historical processes of its current distribution. In total, 169 unique haplotypes were obtained, and phylogenetic trees showed 2 genetically distinct lineages: the Pacific Ocean and the Sea of Japan lineages, whose divergence was estimated to have occurred in the early Pleistocene, related to the paleoenvironmental history of the Sea of Japan. After the divergence, the Sea of Japan lineage rapidly attained its current distribution, whereas the present-day distribution of the Pacific Ocean lineage was formed as a result of vicariance and dispersal.
\end{abstract}

KEY WORDS: Phylogeography • Japanese Archipelago • Pleistocene glacial cycles • Chaenogobius annularis · Mitochondrial DNA $\cdot$ Intertidal goby

Resale or republication not permitted without written consent of the publisher

\section{INTRODUCTION}

In the marine realm, evidence is accumulating that coastal marine species have been strongly affected by the Pleistocene glacial-interglacial cycles (Maggs et al. 2008). For example, low sea levels during glacial maxima created land bridges that brought changes in ocean circulation patterns, which effectively divided marine populations (Avise 2000). Reconstructing these histories is important for predicting the effects of future environmental changes on the distribution of coastal marine species (Pearson \& Dawson 2003, Pearson 2006).

Paleontological and palynological records, as well as a large body of biogeographical data, indicate that many species have undergone dramatic latitudinal shifts in response to climatic change (Bennett et al. 1991, Williams et al. 1998). For organisms that lack a fossil record, genetic data also have been widely used to infer changes in the geographical distribution of species (Hewitt 1999, 2001). In particular, many groups of marine organisms have left few or no fossil records, so genetic data have been particularly informative in reconstructing the history of marine species (Provan \& Bennett 2008). More recently, phylogeography based on molecular markers (Avise 2000) has provided new insights into the historical processes of species distribution during the Pleistocene epoch (Dawson et al. 2001, Hewitt 2004, Ikeda \& Setoguchi 2006, Provan \& Bennett 2008).

Phylogeographic studies have been used to infer the impacts of past climatic changes and the following geomorphic changes on species distribution using the evolutionary rate of the species (e.g. Taberlet et al. 1998, Dawson et al. 2001, Brown \& Stepien 2008). Basically, the evolutionary rate is determined by calibrating differences in genes against an estimate of lineage divergence time or lineage expansion time, based on fossil (Watanabe et al. 2003) or paleobiogeographic data (Tringali et al. 1999). On 
the other hand, many studies have used 'universal' evolutionary rates that have been estimated for other related species. However, the use of a universal evolutionary rate without careful consideration could be problematic because the rate often varies among lineages, even closely related ones (Zhang \& Ryder 1995). It is therefore better to use the evolutionary rate of the species under study based on an appropriate calibration point, fossil, or precise time for geomorphic changes associated with the isolation of geological populations. As mentioned earlier, because many groups of marine organisms leave little or no fossil record (Provan \& Bennett 2008), knowledge of the time of geomorphic changes, which might have impacted the distribution of species, is valuable for evolutionary rate calibration.

Oscillatory changes in the marine environments around the Japanese Archipelago were remarkable during the Pleistocene, particularly in the Sea of Japan, located between Japan and the Asian continent. The Sea of Japan is a semi-enclosed sea connected to the Pacific Ocean and other seas through shallow and narrow straits with sill depths of $<130 \mathrm{~m}$. Today, the warm Tsushima Current flows into the Sea of Japan through the southern Tsushima Straits. However, the Sea of Japan was believed to be largely isolated from the surrounding seas during the multiple glacial periods commencing 2.5 million years ago (MYA; Tada 1994). Several phylogeographic studies have indicated that these events led to the genetic divergence of Japanese coastal marine species between the Pacific Ocean and the Sea of Japan (Kojima et al. 1997, 2004, Akihito et al. 2008, Kokita \& Nohara 2011). Therefore, the spatial patterns of genetic variation of these species are considered to reflect the paleoenvironmental history of the Sea of Japan, for which stratigraphy and chronology have been established independently for the fossiliferous strata (e.g. Oba et al. 1991, Tada et al. 1999, Gorbarenko \& Southon 2000). It has been suggested that inflow from the Tsushima Current occurred during each interglacial period following the middle Pleistocene (Kitamura et al. 2001, Kitamura \& Kimoto 2006). If this is the case, we may elucidate the historical processes that have led to the current distribution of coastal marine species, which have Pacific Ocean and Sea of Japan lineages, by calibrating their evolutionary rates based on the well-dated paleoenvironmental events in the Sea of Japan.

Chaenogobius annularis is a common Japanese intertidal goby that is distributed throughout the rocky coastline of Japan (Hokkaido southward to Yakushima Island) and Korea (Akihito et al. 2002).
Because its life history depends on coastal area environment (Nakamura 1936, Sasaki \& Hattori 1969), as a coastal marine species having both Pacific Ocean and Sea of Japan lineages, the Pleistocene isolation events of the Sea of Japan might have resulted in genetic divergence within $C$. annularis. Moreover, we have detected substantial genetic differentiation between Pacific Ocean and Sea of Japan populations in this species by preliminary allozyme analysis (Hirase et al. 2012). Therefore, we selected C. annularis as a model system, and attempted to elucidate its genetic divergence by mitochondrial DNA markers and reconstruct its history by calibrating its evolutionary rate based on Pleistocene isolation events of the Sea of Japan. We analyzed the phylogeography of $C$. annularis on the basis of the nucleotide sequences of part of the mitochondrial gene for cytochrome $b$ (cyt $b$ ), NADH dehydrogenase subunit 2 (ND2), and the surrounding transfer RNA (tRNA), obtained from specimens collected in 27 localities that cover the distribution area of this species. Our aims were to (1) confirm the existence of discrete Pacific Ocean and Sea of Japan lineages; (2) determine the appropriate calibration point for the evolutionary rate by linking the divergence of these lineages to the paleoenvironmental history of the Sea of Japan; and (3) reconstruct the historical processes that may have led to the current distributions based on the calibrated evolutionary rate.

\section{MATERIALS AND METHODS}

\section{Samples and DNA sequencing}

Sampling localities are shown in Fig. 1 (see also Table 1). Samples of Chaenogobius annularis were collected by hand net from 25 localities on the Japanese coastline (totaling 181 specimens) and from 2 localities on the coastline of the Korean Peninsula (totaling 14 specimens) between 2006 and 2009. C. gulosus was collected at Misaki in Osaka Prefecture, Japan. Total genomic DNA was extracted from the fins of 195 samples, using a phenol/chloroform procedure (Asahida et al. 1996). The DNA samples were stored at $-30^{\circ} \mathrm{C}$ prior to polymerase chain reaction (PCR) analysis. We amplified the cyt $b$ and ND2 genes and surrounding tRNA (Thr, Trp, Ala, Asn). Cyt $b$ and tRNA-Thr were amplified using primers AJG15 and H5 (Akihito et al. 2000); ND2, tRNA-Trp, tRNA-Ala, and tRNA-Asn were amplified using primers ND2B-L (developed by T. Dowling) and H6219 (Yagishita \& Nakabo 2003). For amplification, 
the following reagents were added to each microtube: $1 \mu \mathrm{l}$ of template DNA, $0.25 \mathrm{U}$ of Blend Taq -Plus- (TOYOBO), $1 \mu \mathrm{l}$ of buffer for Blend Taq -Plus$(10 \times), 1 \mu \mathrm{l}$ of each deoxyribonucleoside triphosphate $(2 \mathrm{mM})$, and $0.1 \mu \mathrm{l}$ of each primer $(25 \mu \mathrm{M})$. Enough sterile deionized $\mathrm{H}_{2} \mathrm{O}$ was added to each sample to obtain $10 \mu \mathrm{l}$. PCR conditions consisted of 30 cycles of denaturation at $94^{\circ} \mathrm{C}$ for $30 \mathrm{~s}(1 \mathrm{~min}$ for the first denaturation only), annealing at $50^{\circ} \mathrm{C}$ (cyt $b+$ tRNA) or $59^{\circ} \mathrm{C}$ (ND2 + tRNA) for $30 \mathrm{~s}$, and extension at $72^{\circ} \mathrm{C}$ for $1 \mathrm{~min}$ ( $5 \mathrm{~min}$ for the last extension only). The PCR products were purified by the ethanol/EDTA method following the Applied Biosystems (ABI) BigDye Terminator v3.1 Cycle Sequencing Kit Manual. PCR products were bidirectionally sequenced using the ABI BigDye Terminator Cycle Sequencing Kit v3.1 following the manufacturer's instructions and using the same primers used for the amplification. Reactions were purified by the ethanol/EDTA/sodium acetate method described in the above-mentioned manual and analyzed in an ABI 3130 capillary sequencer.

\section{mtDNA analysis}

The identities of sequences were confirmed by BLAST analysis (Altschul et al. 1997) searching of GenBank (http://blast.ncbi.nlm.nih.gov/) and by comparison with published sequences. Sequences were then aligned using CLUSTAL W (Thompson et al. 1994). Arlequin ver. 3.1 (Excoffier et al. 2005) was used to assign individuals to the unique haplotypes that were obtained in this study and were submitted to the DNA Data Bank of Japan (DDBJ; www.ddbj.nig.ac.jp). For the following analyses, except for the estimation of divergence time, concatenated sequences of cyt $b+\mathrm{ND} 2+$ tRNA were used. The mean base composition and ratios of variable:constant, and transitions:transversions, as well as haplotype diversity and nucleotide diversity were calculated using Arlequin ver. 3.1.

Phylogenetic analyses were carried out on unique haplotypes using the neighbor-joining (NJ) method in PAUP* 4.0b (Swofford 2002) and the maximum likelihood (ML) approach in PhyML (Guindon \& Gascuel 2003; www.atgcmontpellier.fr/phyml/). PAUP* $4.0 \mathrm{~b}$ was run for 1000 bootstrap replicates using the ModelTest 3.06 parameters (Posada \& Crandall 1998): invariable sites $(I)=0.5487$, model $=$ GTR, and $\gamma$ distribution $(G)=$ estimated at 1.5004 (shape) and default setting with pairwise deletion of gap sites. PhyML was run for 300 bootstrap replicates using the ModelTest 3.06 parameters: number of substitution types (nst) $=6, I=0.5487$, transition:transversion ratio = estimated, model $=$ GTR, and $G=$ estimated at 1.5004 (shape) and default setting with pairwise deletion of gap sites. The best model was chosen using the Akaike Information Criterion (AIC; Akaike 1974). A congeneric goby, Chaenogobius gulosus (DDBJ accession no.: AB684974 and AB685124; sequenced in this study), and a related non-congener, Gymnogobius petschiliensis (DDBJ accession no.: AY525784), were used as the outgroups.

The geographic structure of genetic variation was assessed using hierarchical analysis of molecular variance (AMOVA; Excoffier et al. 1992), by defining groups in accordance with the results of our phylogenetic analysis and subsequent spatial analysis of molecular variance (SAMOVA; Dupanloup et al. 2002). The significance was tested by 1000 permutations of the original data set. This analysis was performed by Arlequin ver. 3.1. SAMOVA, based on a simulated annealing procedure, was used to define subgroups in SAMOVA 1.0 (Dupanloup et al. 2002). This analysis iteratively seeks the composition of a user-defined number of geographi-

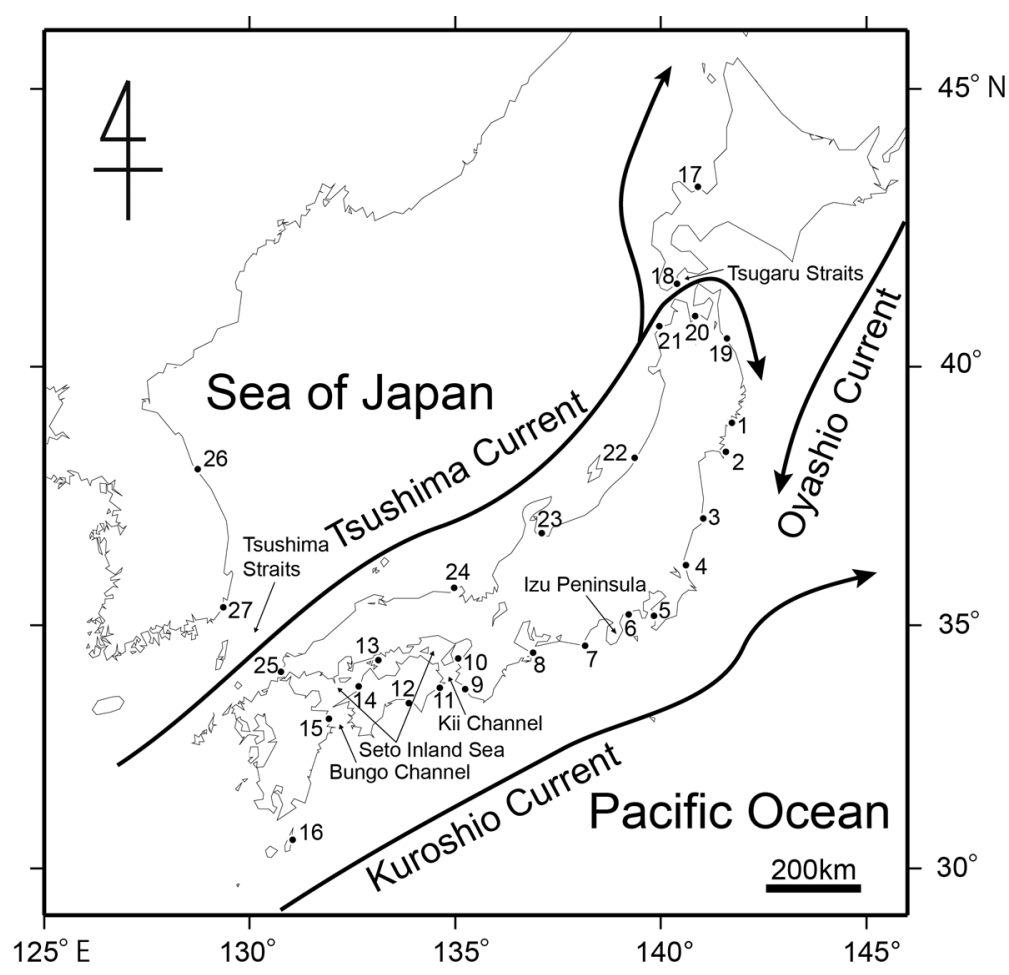

Fig. 1. Sampling localities for Chaenogobius annularis. See also Table 1 for further details 
cal groups $(K)$ that maximizes the fixation index among groups $\left(F_{\mathrm{CT}}\right)$, run here with 100 simulated annealing processes for $K=2$ to 4 .

Demographic histories of geographic groups and subgroups suggested by AMOVA and SAMOVA were inferred using the mismatch distribution analysis (Rogers \& Harpending 1992) implemented in Arlequin ver. 3.1. Populations that experienced a recent bottleneck or sudden expansion are expected to exhibit unimodal distributions, while those at demographic equilibrium should exhibit bimodal or multimodal distributions. Therefore, under an assumption of selective neutrality, mismatch distributions can be used to infer historical periods of population growth and decline. We compared the observed frequency distribution of pairwise nucleotide difference with their expected distribution in a simulated population expansion. For these, goodness-of-fit was evaluated using estimates of the raggedness statistic and the sum of square deviations (SSD). In addition, to provide estimates of change in the effective population size $\left(N_{\mathrm{e}}\right)$, Tajima's $D$-test (Tajima 1989) was performed. These tests were compared to the empirical distribution expected under the neutral model as generated by 1000 simulated re-samplings.

We estimated the time of the most recent common ancestor (TMRCA, Rosenberg \& Feldman 2002) between clades and within clades and subclades based on the construction of linearized trees assuming equal evolutionary rates in different lineages of the tree. In this regard, we described only the TMRCA between the Pacific Ocean and Sea of Japan lineages as 'divergence time.' For this estimation, cyt $b$ and ND2 gene sequences, but not tRNA sequences, were evaluated independently. To create the linearized trees, we first conducted a 2-cluster test and a branch length test to evaluate the evolutionary rates using the software LINTRE (Takezaki et al. 1995), using Tamura-Nei distances for the 125 (cyt b) or 145 (ND2) haplotypes observed in our samples. The tree topologies determined by the NJ method were employed for the test, and Gymnogobius petschiliensis and Chaenogobius gulosus were used as outgroups. Faster or more slowly evolving haplotypes were removed, and the procedure was repeated until the data set contained only sequences evolving at similar rates. We then calculated the height of the branch points of clades and subclades, defined as one-half the average of mean nucleotide differences between them. TMRCA was estimated by the ratio of height to the evolutionary rate. From the result of phylogeographic analysis, we posited that TMRCA for the Sea of Japan lineage cor- responds to one of the times of maximum sea level during the interglacial period of the Pleistocene (i.e.

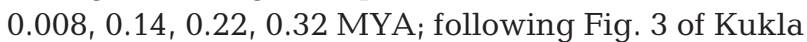
2005), and calibrated the evolutionary rate of $C$. annularis. The reason for this assumption is described in the Discussion.

\section{RESULTS}

\section{Genetic diversity}

A total of 2339 to 2340 bases of mtDNA (cyt $b$ : $1086 \mathrm{bp}$; ND2: $1033 \mathrm{bp}$; tRNA: 220-221 bp) was obtained from each of the 195 specimens of Chaenogobius annularis. The mean percent base composition of the concatenated fragment was 27.30C:31.94T:24.25A:16.51G. It contained 428 polymorphic sites: 375 transitions, 104 transversions, and a single indel in tRNA-Tro, totaling 169 unique haplotypes (DDBJ accession number AB684846-AB684973, AB684975-AB685123). Haplotype diversity and nucleotide diversity of each locality are shown in Table 1 . The mean haplotype diversity $\left(h_{i} \pm\right.$ SD) and nucleotide diversity $\left(\pi_{i} \pm\right.$ $\mathrm{SD})$ of all localities were $0.998 \pm 0.008$ and $4.3 \pm$ $2.1 \%$, respectively.

\section{Phylogeographic analysis}

Phylogenetic relationships among the 169 unique haplotypes were analyzed using NJ and ML methods. The NJ and ML trees with or without Gymnogobius petschiliensis were almost the same, so only the ML tree without $G$. petschiliensis is shown in Fig. 2. All Chaenogobius annularis haplotypes were grouped into 2 genetically and geographically divergent clades, each supported by 97 to $100 \%$ bootstrap probability. One clade was distributed along the Pacific Ocean coast, and the other was distributed mainly along the Sea of Japan coast (Fig. 3); these are termed the Pacific Ocean and the Sea of Japan clades, which differ by an indel. Within the Pacific Ocean clade, all haplotypes except for Hap22 and Hap49 were divided into 5 geographical subclades $(a, b, c, d, e)$, and these subclades were supported by high bootstrap probability (82 to $100 \%$; Fig. 2). In contrast, most Sea of Japan clade haplotypes were closely related, separated by narrow divergence, with no subclades (Fig. 2). There were no localities in which members of the 2 major clades occurred sympatrically. 
Table 1. Chaenogobius annularis. Sampling localities and genetic diversity of each locality. Number in brackets corresponds to position in Fig. 1. $h$ : haplotype diversity; $\pi$ : nucleotide diversity

\begin{tabular}{|c|c|c|c|c|}
\hline Locality, prefecture (no.) & $\begin{array}{l}\text { Latitude, } \\
\text { Longitude }\end{array}$ & $\begin{array}{c}\text { No. of } \\
\text { samples }\end{array}$ & $h$ & $\begin{array}{c}\pi \\
(\%)\end{array}$ \\
\hline \multicolumn{5}{|l|}{ Japan } \\
\hline Ohunato, Iwate (1) & $38^{\circ} 59^{\prime} \mathrm{N}, 141^{\circ} 44^{\prime} \mathrm{E}$ & 8 & 0.857 & 0.3 \\
\hline Onagawa, Miyagi (2) & $38^{\circ} 26^{\prime} \mathrm{N}, 141^{\circ} 27^{\prime} \mathrm{E}$ & 8 & 0.964 & 0.4 \\
\hline Yotsukura, Fukushima (3) & $37^{\circ} 7^{\prime} \mathrm{N}, 141^{\circ} 0^{\prime} \mathrm{E}$ & 8 & 0.893 & 0.2 \\
\hline Hiraiso, Ibaraki (4) & $36^{\circ} 21^{\prime} \mathrm{N}, 140^{\circ} 37^{\prime} \mathrm{E}$ & 8 & 1.000 & 0.4 \\
\hline Takeoka, Chiba (5) & $35^{\circ} 12^{\prime} \mathrm{N}, 139^{\circ} 50^{\prime} \mathrm{E}$ & 8 & 1.000 & 0.2 \\
\hline Enoshima, Kanagawa (6) & $35^{\circ} 17^{\prime} \mathrm{N}, 139^{\circ} 28^{\prime} \mathrm{E}$ & 8 & 1.000 & 0.2 \\
\hline Omaezaki, Shizuoka (7) & $34^{\circ} 35^{\prime} \mathrm{N}, 138^{\circ} 13^{\prime} \mathrm{E}$ & 8 & 0.964 & 0.4 \\
\hline Anrakujima, Mie (8) & $34^{\circ} 27^{\prime} \mathrm{N}, 136^{\circ} 52^{\prime} \mathrm{E}$ & 8 & 1.000 & 0.4 \\
\hline Tanabe, Wakayama (9) & $33^{\circ} 43^{\prime} \mathrm{N}, 135^{\circ} 21^{\prime} \mathrm{E}$ & 3 & 1.000 & 0.4 \\
\hline Misaki, Osaka (10) & $34^{\circ} 19^{\prime} \mathrm{N}, 135^{\circ} 9^{\prime} \mathrm{E}$ & 8 & 1.000 & 0.7 \\
\hline Yuki, Tokushima (11) & $33^{\circ} 46^{\prime} \mathrm{N}, 134^{\circ} 35^{\prime} \mathrm{E}$ & 8 & 1.000 & 0.7 \\
\hline Yasu, Kochi (12) & $33^{\circ} 26^{\prime} \mathrm{N}, 133^{\circ} 23^{\prime} \mathrm{E}$ & 8 & 1.000 & 0.6 \\
\hline Innoshima, Hiroshima (13) & $34^{\circ} 21^{\prime} \mathrm{N}, 133^{\circ} 10^{\prime} \mathrm{E}$ & 2 & 0.000 & 0.0 \\
\hline Iyo, Ehime (14) & $33^{\circ} 42^{\prime} \mathrm{N}, 132^{\circ} 39^{\prime} \mathrm{E}$ & 7 & 1.000 & 0.6 \\
\hline Kamiura, Oita (15) & $33^{\circ} 2^{\prime} \mathrm{N}, 131^{\circ} 56^{\prime} \mathrm{E}$ & 7 & 0.714 & 0.7 \\
\hline Tanegashima, Kagoshima (16) & $30^{\circ} 41^{\prime} \mathrm{N}, 131^{\circ} 4^{\prime} \mathrm{E}$ & 6 & 1.000 & 0.2 \\
\hline Otaru, Hokkaido (17) & $43^{\circ} 14^{\prime} \mathrm{N}, 141^{\circ} 0^{\prime} \mathrm{E}$ & 7 & 0.857 & 0.2 \\
\hline Shiriuchi, Hokkaido (18) & $41^{\circ} 31^{\prime} \mathrm{N}, 140^{\circ} 25^{\prime} \mathrm{E}$ & 8 & 0.893 & 0.3 \\
\hline Hachinohe, Aomori (19) & $40^{\circ} 32^{\prime} \mathrm{N}, 141^{\circ} 33^{\prime} \mathrm{E}$ & 7 & 0.952 & 0.1 \\
\hline Asamushi, Aomori (20) & $40^{\circ} 53^{\prime} \mathrm{N}, 140^{\circ} 51^{\prime} \mathrm{E}$ & 8 & 0.929 & 0.2 \\
\hline Kasose, Aomori (21) & $40^{\circ} 44^{\prime} \mathrm{N}, 139^{\circ} 59^{\prime} \mathrm{E}$ & 6 & 1.000 & 0.3 \\
\hline Majima, Niigata (22) & $38^{\circ} 16^{\prime} \mathrm{N}, 139^{\circ} 26^{\prime} \mathrm{E}$ & 8 & 1.000 & 0.4 \\
\hline Himi, Toyama (23) & $36^{\circ} 48^{\prime} \mathrm{N}, 137^{\circ} 2^{\prime} \mathrm{E}$ & 8 & 1.000 & 0.3 \\
\hline Amino, Kyoto (24) & $35^{\circ} 41^{\prime} \mathrm{N}, 135^{\circ} 2^{\prime} \mathrm{E}$ & 8 & 0.964 & 0.3 \\
\hline Simonoseki, Yamaguchi (25) & $33^{\circ} 57^{\prime} \mathrm{N}, 130^{\circ} 52^{\prime} \mathrm{E}$ & 8 & 0.964 & 0.5 \\
\hline \multicolumn{5}{|l|}{ Korea } \\
\hline Yeongok, Gangneung (26) & $37^{\circ} 51^{\prime} \mathrm{N}, 128^{\circ} 51^{\prime} \mathrm{E}$ & 7 & 0.762 & 0.0 \\
\hline Gijang, Pusan (27) & $35^{\circ} 12^{\prime} \mathrm{N}, 129^{\circ} 13^{\prime} \mathrm{E}$ & 7 & 0.952 & 0.3 \\
\hline
\end{tabular}

AMOVA was performed first at the level of the 27 sampling localities (fixation index among localities $\left.\left[F_{\mathrm{ST}}\right]=0.922, \mathrm{p}<0.001\right)$; these were then divided into 2 groups (the Pacific Ocean and the Sea of Japan group), which distributed a significant portion of genetic variance $\left(F_{\mathrm{CT}}=0.893, \mathrm{p}<0.001\right)$ between them, as well as among sites within them (Table 2).

The genetic structure of each of the 2 clades was then analyzed separately. $h$ and $\pi$ of the Pacific Ocean group were 0.998 and $1.2 \%$, respectively. AMOVA showed that significant genetic variance $\left(F_{\mathrm{ST}}=0.618, \mathrm{p}<0.001\right)$ was distributed among collection localities in the Pacific Ocean (Table 2). SAMOVA suggested that opti-

Fig. 2. (Right and following page.) Chaenogobius annularis. (A) Maximum likelihood (ML) tree of 169 haplotypes estimated by PhyML using the GTR + I + G model. Branch lengths are proportional to the estimated number of nucleotide substitutions per site. Numbers above branches indicate the bootstrap probabilities calculated by ML (left) and neighbor-joining (NJ, right) methods. Letters indicate subclade names. (B) Enlarged view of the Pacific Ocean and Sea of Japan clades mum partitioning was obtained when localities were divided into 3 subgroups (Fig. 3) since $F_{\mathrm{CT}}$ reached a plateau at $K=3$ and 1 or more groups contained a single locality for $K \geq 3$, indicating loss of group structure. Significant genetic variance $\left(F_{\mathrm{CT}}=0.513, \mathrm{p}<0.001\right.$; Table 2$)$ was then distributed among and within these subgroups $\left(F_{\mathrm{ST}}=0.296-0.362, \mathrm{p}<0.01\right.$;

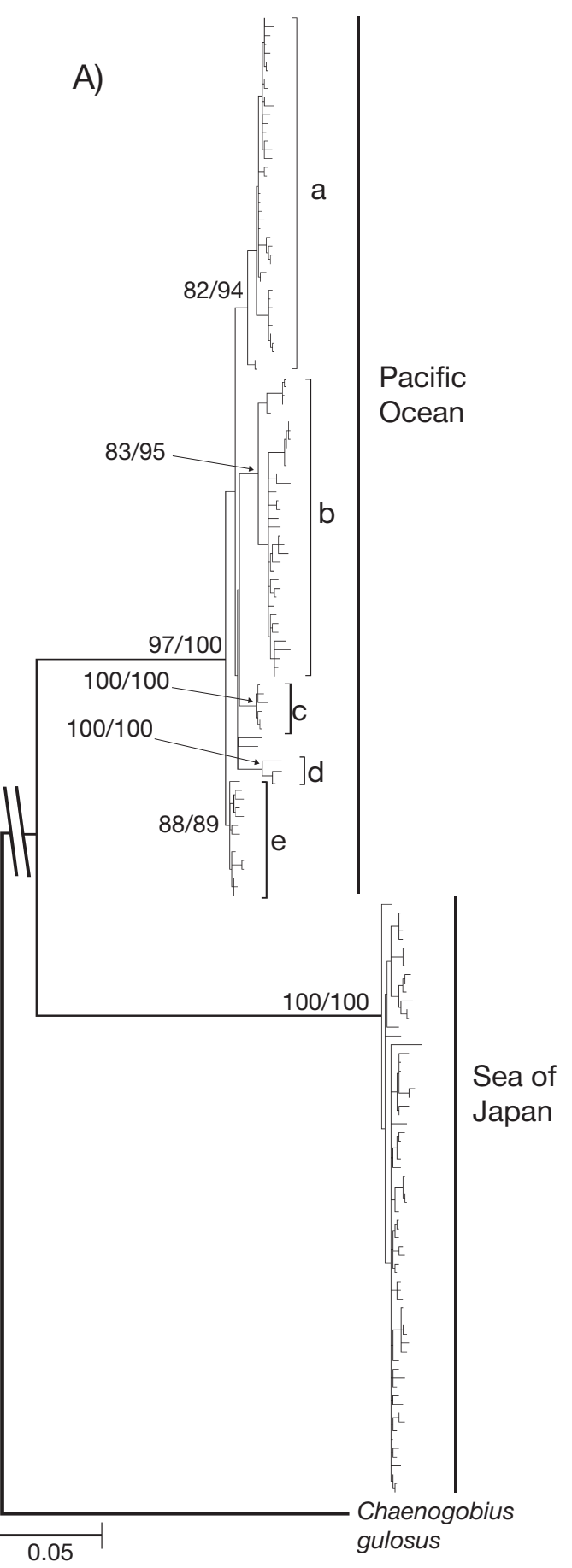




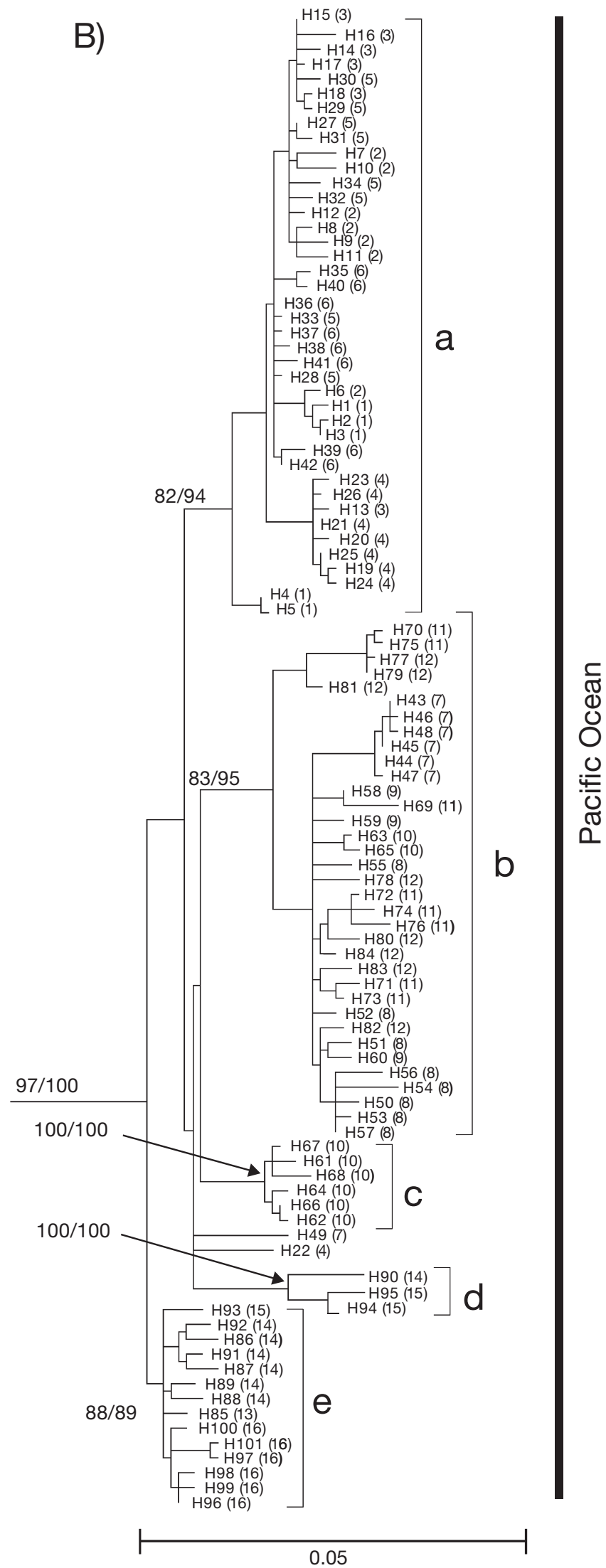

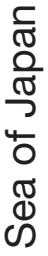

Fig. 2 (continued) 


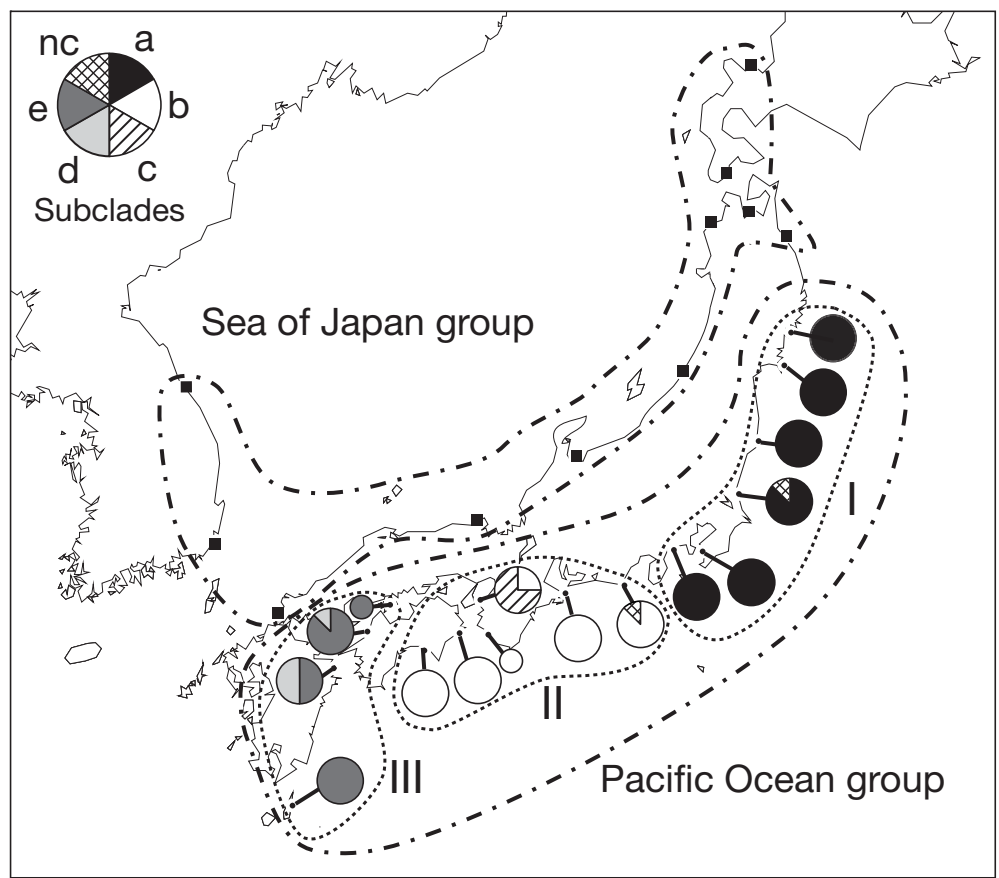

Fig. 3. Chaenogobius annularis. Geographic distributions of the Pacific Ocean clade (Subclades a-e; nc indicates haplotypes not belonging to any subclades) and Sea of Japan clade (black squares). There were no localities in which members of the 2 major clades occurred sympatrically. Roman numerals show the subgroups inferred by spatial analysis of molecular variance (SAMOVA) bution for the Sea of Japan group was consistent with a sudden population expansion. Neither mismatch distribution yielded significant $(\mathrm{p}>0.05) \mathrm{SSD}$ or raggedness indices, and the suddenexpansion hypothesis for the Sea of Japan group was also supported by a significantly negative value of Tajima's $D$ $(-2.14 ; \mathrm{p}<0.01)$.

The mismatch distributions of subgroups within the Pacific Ocean group differed from each other (Fig. 4), although a model of sudden expansion did fit all subgroups due to nonsignificant $(\mathrm{p}>0.05)$ SSD and raggedness indices. Despite this, Subgroup I appeared to be unimodal and had a low mean difference (10.43), consistent with sudden expansion. This observation was supported by the significantly negative value of Tajima's $D(-2.14$; $\mathrm{p}<0.01$ ). Subgroup II was either bimodal or multimodal and had a high mean number of differences (18.62), consistent with a constant population size. Subgroup III was clearly bimodal, consistent with the presence of distinct lineages.
Table 2). Haplotype diversity and nucleotide diversity of the Sea of Japan group were 0.995 and $0.6 \%$, respectively, with the latter being half that of the Pacific Ocean group. AMOVA showed that significant genetic variance $\left(F_{\mathrm{ST}}=0.535, \mathrm{p}<0.001\right)$ was distributed among collection localities of the Sea of Japan group (Table 2); however, SAMOVA analysis suggested that it contained no subgroups.

\section{Historical demography}

The mtDNA mismatch distribution of the Pacific Ocean group and the Sea of Japan group exhibited contrasting patterns (Fig. 4). The overall distribution for the Pacific Ocean group was multimodal and had high mean differences (25.43), consistent with constant population size. Conversely, the unimodal distribution and low mean differences (12.88) in distri-
Table 2. Chaenogobius annularis. Hierarchical analysis of molecular variance (AMOVA) of mtDNA haplotypes. See Fig. 3 for group locations. Fixation index: $p<0.001$ except for Subgroup III where $p=0.004$. SAMOVA: spatial AMOVA

\begin{tabular}{|llrrr|}
\hline Comparison & \multicolumn{1}{c}{$\begin{array}{c}\text { Source of } \\
\text { variation }\end{array}$} & df & $\begin{array}{c}\text { Fixation } \\
\text { index }\end{array}$ & $\begin{array}{c}\text { Percentage } \\
\text { of variation }\end{array}$ \\
\hline All localities & Among localities & 26 & 0.922 & 92.16 \\
& Within localities & 168 & & 7.84 \\
Two groups & Among groups & 1 & 0.893 & 89.26 \\
(Pacific Ocean/ & Among localities & 25 & 0.591 & 6.35 \\
& within groups & & & \\
Sea of Japan) & Within localities & 168 & 0.956 & 4.39 \\
Pacific Ocean & Among localities & 15 & 0.618 & 61.82 \\
group only & Within localities & 97 & & 38.18 \\
Three subgroups & Among groups & 2 & 0.513 & 51.34 \\
supported by & Among localities & 13 & 0.343 & 16.71 \\
SAMOVA (I/II/III) & within groups & & & \\
& Within localities & 97 & 0.680 & 31.95 \\
Subgroup I only & Among localities & 5 & 0.362 & 36.20 \\
& Within localities & 42 & & 63.80 \\
Subgroup II only & Among localities & 5 & 0.348 & 34.76 \\
& Within localities & 37 & & 65.24 \\
Subgroup III only & Among localities & 3 & 0.296 & 29.61 \\
& Within localities & 18 & & 70.39 \\
Sea of Japan & Among localities & 10 & 0.535 & 51.11 \\
group only & Within localities & 71 & & 48.89 \\
\hline
\end{tabular}



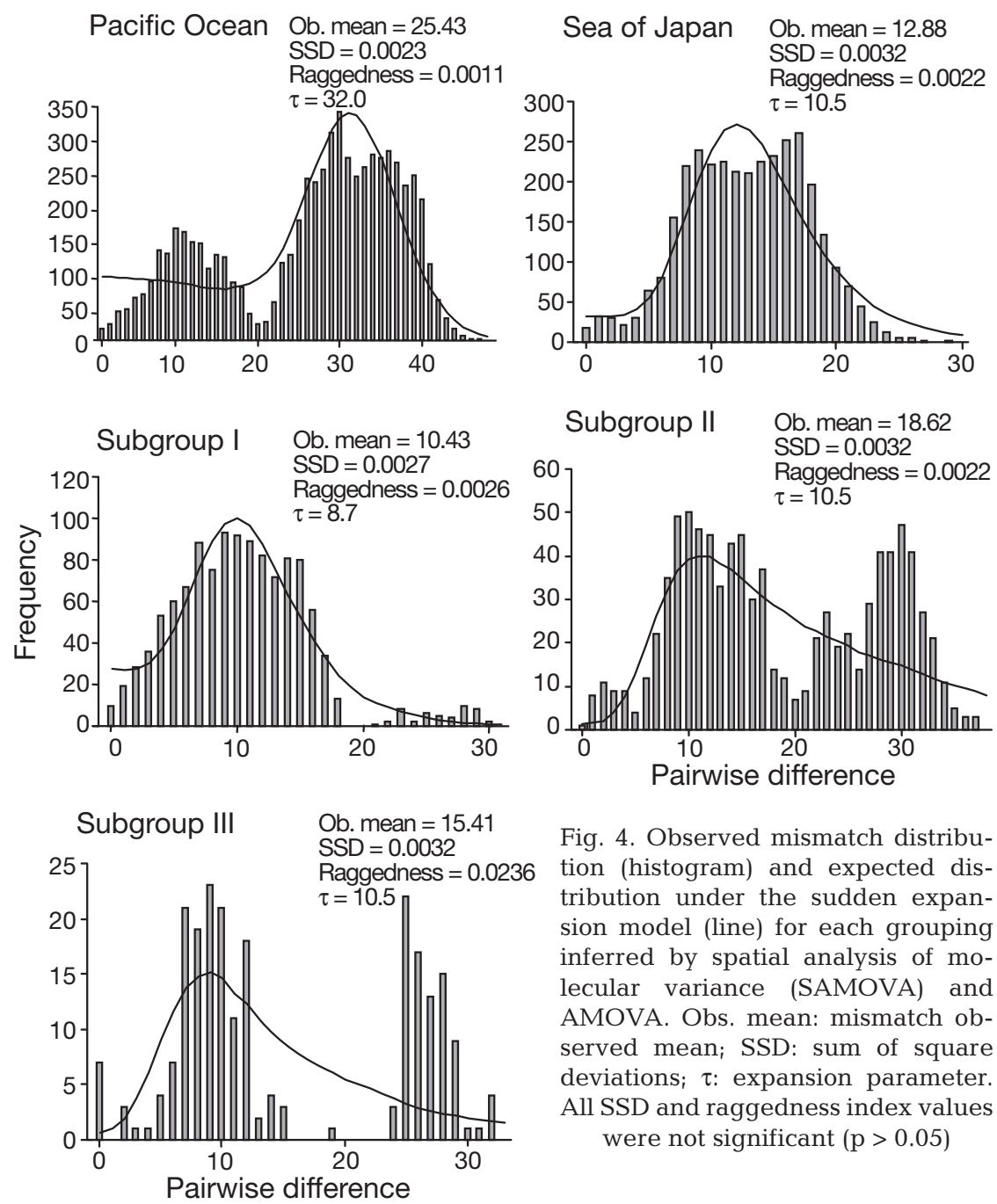

Fig. 4. Observed mismatch distribution (histogram) and expected distribution under the sudden expansion model (line) for each grouping inferred by spatial analysis of molecular variance (SAMOVA) and AMOVA. Obs. mean: mismatch observed mean; SSD: sum of square deviations; $\tau$ : expansion parameter. All SSD and raggedness index values were not significant $(p>0.05)$

\section{Estimation of divergence time between Pacific Ocean and Sea of Japan lineages}

The results of the 2-cluster tests are summarized in Table 3, which indicated that the evolutionary rate of cyt $b$ did not differ significantly between the Pacific Ocean and the Sea of Japan clades. On the other hand, the rate of ND2 differed significantly $(p<0.05)$ between them. The branch-length test also supported a relatively constant rate of evolution for all haplotypes in cyt $b$, but not in ND2. Given these results, we used only cyt $b$ to estimate the divergence time between the Pacific Ocean and Sea of Japan lineages, which is shown in Table 4 . The evolutionary rate ranged from 1.5 to $61.0 \%$, and the divergence time ranged from 0.06 to 2.46 MYA. The linearized tree of cyt $b$ was almost the same as that of the concatenated cyt $b+\mathrm{ND} 2+\mathrm{tRNA}$; however, they differed in composition of the Pacific Ocean clade. Thus, we estimated TMRCA only for subclades $\mathrm{a}$ and $\mathrm{c}$ in the following discussion because their compositions were congruent.

\section{DISCUSSION}

Table 3. Chaenogobius annularis. Results of 2-cluster test for Pacific Ocean and Sea of Japan clades. CP: confidence probability $(1-\mathrm{p})$ computed in the 2 -cluster test; $b_{\mathrm{pc}}$ : branch length of the Pacific Ocean clade; $b_{\mathrm{sj}}$ : branch length of the Sea of Japan clade; delta: $\left|b_{\mathrm{pc}}-b_{\mathrm{sj}}\right| ; Z$ : delta/SE; height: average $\left(b_{\mathrm{pc}}, b_{\mathrm{sj}}\right){ }^{*} \mathrm{p}<0.05$

\begin{tabular}{|lcccccc|}
\hline Region & $\mathrm{CP}(\%)$ & $b_{\mathrm{pc}}$ & $b_{\mathrm{sj}}$ & Delta & $Z$ & Height \\
\hline Cyt $b$ & 71.08 & 0.0336 & 0.0411 & 0.0075 & 1.07 & 0.0374 \\
ND2 & $98.96^{*}$ & 0.0431 & 0.0708 & 0.0277 & 2.56 & 0.0570 \\
\hline
\end{tabular}

\section{Divergence between Pacific Ocean and Sea of Japan lineages}

The phylogenetic trees and AMOVA of Chaenogobius annularis from mtDNA supported a primary division between the Pacific Ocean and Sea of Japan lineages. This pattern resulted from multiple isolation events of the Sea of Japan during Pleistocene glacial periods, as found for Pterogobius elapoides

Table 4. Chaenogobius annularis. Estimation of divergence time between the Pacific Ocean and Sea of Japan clades. TMRCA: time of most recent common ancestor; IG: interglacial period; MY: million years; MYA: million years ago

\begin{tabular}{|lcccc|}
\hline TMRCA of Sea of Japan lineage & 0.008 MYA & Riss-Würm IG & Mindel-Riss IG & Günz-Mindel IG \\
& & 0.14 MYA & 0.32 MYA \\
\hline Evolutionary rate (\% per MY) & 61.0 & 3.4 & 2.2 & 1.5 \\
Divergence time (MYA) & 0.06 & 1.08 & 1.69 & 2.46 \\
\hline
\end{tabular}


(Akihito et al. 2008), P. zonoleucus (Akihito et al. 2008), Turbo (Batillus) cornutus (Kojima et al. 1997), Batillaria cumingi (Kojima et al. 2004), and Leucopsarion petersii (Kokita \& Nohara 2011).

We found sharp contrasts in genetic diversity and branching patterns of the phylogenetic trees between the Pacific Ocean and Sea of Japan groups. When a population is constant in size, each female is replaced on average by 1 female descendant in each generation; hence, the number of mtDNA lineages remains approximately constant over time (Avise et al. 1984, Grant \& Bowen 1998, Di Rienzo \& Wilson 1991). In contrast, in an expanding population, each female is replaced by more than 1 female descendant, and the number of mtDNA lineages increases; thus, mutations have a higher probability of being retained in the population. In other words, the stochastic loss of lineages declines in an expanding population, and the frequency of new branch points (per unit time) in the tree increases (Avise et al. 1984, Di Rienzo \& Wilson 1991, Grant \& Bowen 1998). Therefore, we conclude that the high genetic diversity and 'deep' branching pattern of the Pacific Ocean lineage elucidate a comparatively long evolutionary history, while the low genetic diversity and 'shallow' branching pattern of the Sea of Japan lineage reflect a sudden increase in the probability of survival of mtDNA lineages due to a burst of population growth, i.e. a sudden expansion. These scenarios are further supported by the mtDNA mismatch distributions and Tajima's $D$ tests. Similar patterns of genetic diversity and branching in the phylogenetic tree of the Sea of Japan lineage of Chaenogobius annularis have been described in studies on other Japanese coastal marine species of Pacific Ocean and Sea of Japan lineages (Kojima et al. 2004, Akihito et al. 2008, Kokita \& Nohara 2011). Therefore, the Sea of Japan lineages of these species, including $C$. annularis, might have experienced a sudden expansion promoted by common environmental factors associated with paleoenvironmental events during the Pleistocene.

The Sea of Japan was nearly isolated from surrounding seas because of the closing of the Tsushima Straits due to a fall in sea level during glacial periods, with colder temperatures resulting from loss of the warm Tsushima Current, and lower salinity due to excess input of freshwater from rivers (Oba et al. 1991, Tada 1994, Gorbarenko \& Southon 2000). Therefore, the Sea of Japan was regarded to be a severe environment for marine warm-water species such as Chaenogobius annularis during these periods. On the other hand, during interglacial periods, with the inflow of the warm Tsushima Current (Kitamura et al. 2001, Kitamura \& Kimoto 2006), the environment of the Sea of Japan was estimated to be much less severe during these periods. Therefore, it is likely that the sudden expansion of the Sea of Japan lineage was caused by a rise in sea level and the subsequent inflow of the Tsushima Current in interglacial periods. The impact of the Tsushima Current on the Sea of Japan lineage is indicated by the correspondence between the area where the current flows and the distribution of this lineage. In addition, several phylogeographic studies have indicated a sudden expansion in marine species abundances during the interglacial periods (Provan et al. 2005, Hoarau et al. 2007).

Therefore, we assumed that the TMRCA of the Sea of Japan lineage, which is considered the lower boundary for the expansion, corresponds to the time of maximum sea level in one of the late Pleistocene interglacial periods, and calculated the evolutionary rate and divergence time between the Pacific Ocean and the Sea of Japan lineages using cyt $b$. When we assumed that the TMRCA of the Sea of Japan lineage was $0.008 \mathrm{MYA}$, the evolutionary rate was estimated to be $61.0 \%$ per million years (MY). This rate is greatly overestimated in comparison with the estimated rates for fish cyt $b$ between $0.8 \%$ per MY (Cantatore et al. 1994) and 2.8\% per MY (Orti et al. 1994). Therefore, this assumption is unlikely. On the other hand, the other 3 assumptions appear reasonable because the estimated evolutionary rates were close to the above rates. Among these assumptions, the assumption that the TMRCA of the Sea of Japan lineage was the Mindel-Riss interglacial (0.22 MYA) results in an estimation of $2.2 \%$ per MY. This rate is comparable to the prior estimates for Gymnogobius spp., a species related to Chaenogobius annularis, of 2.2 to $2.4 \%$ per MY (Harada et al. 2002) and $2.7 \%$ per MY (Sota et al. 2005). Harada et al. (2002) calibrated the evolutionary rate assuming that $G$. isaza, an endemic species in Lake Biwa, Japan, which has an offshore life history in deep areas, originated when the lake became deepest, and Sota et al. (2005) calibrated the evolutionary rate assuming that the genetic divergence of the continental freshwater goby G. taranetzi and the Japanese G. castaneustaranetzi corresponds to the periods when the Tsushima Current began to flow into the Sea of Japan. These assumptions are reasonable, and these calibration points differ from ours. Thus, these evolutionary rates are plausible references for comparison. In addition, this TMRCA is close to that of the major Sea of Japan lineage of ice goby Leucopsarion peter- 
sii (0.29-0.23 MYA, Kokita \& Nohara 2011). Given an evolutionary rate of $2.2 \%$ per MY, the divergence time between the Pacific Ocean and the Sea of Japan lineages can be estimated to have occurred 1.7 MYA, during the early Pleistocene. Paleoenvironmental studies have suggested that 1.7 MYA was an important turning point for the Sea of Japan because the southern straits of the Sea of Japan opened on a large scale around this period (Kitamura et al. 2001, Kitamura \& Kimoto 2006), and Kitamura (2010) suggested that the southern marine species started to enter the Sea of Japan 1.7 MYA through the southern straits. Thus it is a reasonable scenario that the ancestral $C$. annularis lineages dispersed through the strait, and following multiple isolation events of the Sea of Japan during the Pleistocene, resulted in a division of the 2 lineages. Because the evolutionary rate and the associated divergence time are consistent with previous genetic and paleoenvironmental studies, we posit that the sudden expansion of the Sea of Japan lineage linked to the Mindel-Riss interglacial period is more plausible than the others.

\section{Formative history and distribution of the Pacific Ocean and Sea of Japan lineages}

The divergence times estimated for other coastal marine species similarly divided into 2 lineages in these regions range from 0.9 MYA to 0.03 MYA (Leucopsarion petersii: 0.9-0.7 MYA, Kokita \& Nohara 2011; Pterogobius elapoides: 0.05-0.03 MYA, Akihito et al. 2008; Pterogobius zonoleucus: 0.60-0.39 MYA, Akihito et al. 2008). This range is likely to reflect multiple isolation events in the Sea of Japan. On the other hand, the divergence time of Chaenogobius annularis is generally older than these times. Thus, $C$. annularis might be one of the early marine colonizers in the Sea of Japan. Persistence of the Sea of Japan lineage to the present time indicates that this lineage has survived for 1.7 MY despite repeated unfavorable climatic conditions of the Pleistocene ice ages.

This lineage is now distributed along the Japanese and Korean coasts facing the Sea of Japan and the Sanriku Coast up to Hachinohe (locality 19 in Fig. 1) in the Pacific Ocean. Because this distribution area corresponds to the range along which the Tsushima Current flows, the distribution area was likely formed by the inflow of the Tsushima Current in the interglacial period after 0.22 MYA. Because no subclades were supported by bootstrap analyses and no genetic structure was detected by SAMOVA within the Sea of Japan lineage, our results indicate that the lineage rapidly radiated and has maintained high gene flow.

In contrast to the Sea of Japan lineage, 5 well supported geologically discrete subclades within the Pacific Ocean clade indicate vicariance dating to after 0.30 MYA. This clear structure in the Pacific Ocean group likely indicates the low dispersal ability of Chaenogobius annularis, as noted in ecological studies on this species (Nakamura 1936, Sasaki \& Hattori 1969). Three subgroups were supported by SAMOVA, whose boundaries are likely to be related to the sea level fall in glacial periods. The first geographic partition between Subgroups I and II was the surrounding Izu Peninsula. To the east and west of the Izu Peninsula are 2 deep bays, Suruga and Sagami, whose respective depths are approximately 2500 and $1500 \mathrm{~m}$ (Coastal Oceanography Research Committee 1985). Their deep troughs run into closed-off sections, with narrow continental shelves that are very small in area and drop off suddenly, leaving little suitable habitat for this goby (Coastal Oceanography Research Committee 1985, Matsuyama et al. 1993, Katayama et al. 2008). Therefore, the shallow coastal areas which were suitable for $C$. annularis likely disappeared from the above 2 bays due to the sea level fall in the Pleistocene glacial periods, resulting in vicariant separation. The surrounding Bungo Channel forms the boundary between Subgroups II and III, which likely was not a historical barrier. It has been estimated that drying up of the Seto Inland Sea resulted from a fall in sea level during the glacial periods, leading to the formation of 2 large rivers that flow into the Kii and Bungo Channels, respectively (Kaizuka et al. 1995). Thus, the large rivers led to restricted gene flow in the Bungo Channel, leading to the differentiation between Subgroups II and III. However, we observed no evidence of restricted gene flow in the Kii Channel. Secondary contact between subpopulations that became separated by topographical changes in the area surrounding the Seto Inland Sea in glacial periods may have led to the coexistence of genetically divergent sub-lineages in several localities (Misaki, Iyo, Kamiura), as indicated by our TMRCA Subclade c (dated to 50000 yr ago based on $2.2 \%$ per MY), corresponding to the last glacial periods.

Restricted gene flow among Pacific Ocean subgroups led to different demographic histories for each group. Results from Tajima's $D$-tests and mismatch distribution analysis suggested sudden expansion of Subgroup I, which may be related to the dynamics of the Kuroshio and Oyashio Currents. For 
example, Niimura et al. (2006) studied paleoenvironmental changes off the coast of Kashima, Ibaraki Prefecture (around locality 4 in Fig. 1), in the Pacific Ocean during the last $144000 \mathrm{yr}$ based on the planktonic foraminiferal assemblage. They hypothesized that sea temperatures $130000 \mathrm{yr}$ ago were $10^{\circ} \mathrm{C}$ colder than present due to the southward advance of the cool Oyashio Current, and became warmer from 120000 to $69000 \mathrm{yr}$ ago due to the northward advance of the warm Kuroshio Current. The latter may have led to the sudden expansion of Subgroup I. In fact, it has been reported that Chaenogobius annularis does not inhabit the area northwest of Hokkaido (Matsuura \& Shinohara 2006) where the force of the Oyashio Current is strong. The TMRCA (dated to 0.17 MYA based on $2.2 \%$ per MY) of Subclade a does not conflict with the above scenario very much.

The mismatch distribution for Subgroup II was bimodal or multimodal, indicating that this subgroup appears to have been stable for a long time. Thus, the physical and environmental conditions where Subgroup II is distributed might have been stable for Chaenogobius annularis due to the influence of the Kuroshio Current. The mismatch distribution of Subgroup III was clearly bimodal, so secondary contact of several sub-lineages was likely to occur in association with topographical changes in the area surrounding the Seto Inland Sea as mentioned above.

In other Japanese coastal marine species having discrete Pacific Ocean and Sea of Japan lineages, both lineages are often found to co-occur in boundary areas that separate them, for example, around the Seto Inland Sea and the Sanriku Coast (Kojima et al. 2004, Kokita \& Nohara 2011). Kokita \& Nohara (2011) showed that hybridization and introgression between 2 lineages of Leucopsarion petersii have occurred in the boundary areas. In contrast to such species, the geographic ranges of the Pacific Ocean and Sea of Japan lineages of Chaenogobius annularis do not overlap. However, if directional hybridization has occurred today and/or in Pleistocene interglacial periods, mtDNA markers cannot detect it absolutely due to its maternal inheritance (Lamb \& Avise 1986). Thus, in future studies we must investigate the secondary contact zone by thorough sampling in the boundary areas, and verify whether hybridization has occurred based on nuclear markers. In addition, it is necessary to perform morphological analyses of the 2 groups of $C$. annularis, due to a lack of knowledge on morphological differences. Through such analyses, we would aim to assess whether isolation events in the Sea of Japan led to reproductive isolation and trait differentiation between the 2 geographical groups.

In conclusion, using a calibrated, rather than a universal, evolutionary rate based on the well-dated paleoenvironmental events in the Sea of Japan, we have been able to deduce a reasonably accurate evolutionary history of Chaenogobius annularis. Our phylogeographic study indicates that the cycles of vicariance and dispersal during the early to middle Pleistocene epoch resulted in the current distribution area and genetic structure of $C$. annularis. This study contributes to understanding the role that paleoenvironmental events around the Japanese Archipelago have played in the distribution of coastal marine species.

Acknowledgements. We thank Y. Ikeda, S. Arakaki, T. Sugaya, K. Sakamoto, T. Shimizu, S. Hong and W. Nam for providing specimens. Primer information for DNA analysis was provided by T. Gojobori and Y. Umehara. This study was supported by the Mikimoto Fund for Marine Ecology, the Global COE Program 'Center for Ecosystem Management Adapting to Global Change' (J03) of the Ministry of Education, Culture, Sports, Science, and Technology of Japan. The staff of the Onagawa Field Science Center, Graduate School of Agricultural Science, Tohoku University, assisted in the collection of samples.

\section{LITERATURE CITED}

Akaike H (1974) A new look at the statistical model identification. IEEE Trans Automat Control 19:716-723

Akihito, Iwata A, Kobayashi T, Ikeo K and others (2000) Evolutionary aspects of gobioid fishes based upon a phylogenetic analysis of mitochondrial cytochrome $b$ genes. Gene 259:5-15

Akihito, Sakamoto K, Ikeda Y, Sugiyama K (2002) Gobioidei. In: Nakabo T (ed) Fishes of Japan with pictorial keys to the species, English edn. Tokai University Press, Tokyo, p 1139-1310, 1596-1620

Akihito, Fumihito A, Ikeda Y, Aizawa M and others (2008) Evolution of Pacific Ocean and the Sea of Japan populations of the gobiid species, Pterogobius elapoides and Pterogobius zonoleucus, based on molecular and morphological analyses. Gene 427:7-18

Altschul SF, Madden TL, Schäffer AA, Zhang J, Zhang Z, Miller W, Lipman DJ (1997) Gapped BLAST and PSIBLAST: a new generation of protein database search programs. Nucleic Acids Res 25:3389-3402

Asahida T, Kobayashi T, Saitoh K, Nakayama I (1996) Tissue preservation and total DNA extraction from fish stored at ambient temperature using buffers containing high concentration of urea. Fish Sci 62:727-730

Avise JC (2000) Phylogeography: the history and formation of species. Harvard University Press, Cambridge, MA

Avise JC, Neigel JE, Arnold J (1984) Demographic influences on mitochondrial DNA lineage survivorship in animal populations. J Mol Evol 20:99-105

Bennett KD, Tzedakis PC, Willis KJ (1991) Quaternary refugia of north European trees. J Biogeogr 18:103-115 
Brown JE, Stepien CA (2008) Ancient divisions, recent expansions: phylogeography and population genetics of the round goby Apollonia melanostoma. Mol Ecol 17: 2598-2615

> Cantatore P, Roberti M, Pesole G, Ludovico A, Milella F, Gadaleta MN, Saccone C (1994) Evolutionary analysis of cytochrome $b$ sequences in some Perciformes: evidence for a slower rate of evolution than in mammals. J Mol Evol 39:589-597

Coastal Oceanography Research Committee (1985) The Oceanographical Society of Japan: coastal oceanography of the Japanese Islands. Tokai University Press, Tokyo (in Japanese)

> Dawson MN, Staton JL, Jacobs DK (2001) Phylogeography of the tidewater goby, Eucyclogobius newberryi (Teleostei, Gobidae), in coastal California. Evolution 55: 1167-1179

> Di Rienzo A, Wilson AC (1991) Branching pattern in the evolutionary tree for human mitochondrial DNA. Proc Natl Acad Sci USA 88:1597-1601

> Dupanloup I, Schneider S, Excoffier L (2002) A simulated annealing approach to define the genetic structure of populations. Mol Ecol 11:2571-2581

Excoffier L, Smouse PE, Quattro JM (1992) Analysis of molecular variance inferred from metric distances among DNA haplotypes: application to human mitochondrial DNA restriction data. Genetics 131:479-491

Excoffier L, Laval G, Schneider S (2005) Arlequin ver. 3.0. An integrated software package for population genetics data analysis. Evol Bioinform Online 1:47-50

> Gorbarenko SA, Southon JR (2000) Detailed Japan Sea paleoceanography during the last $25 \mathrm{kyr}$ : constraints from AMS dating and $\delta^{18} \mathrm{O}$ of planktonic foraminifera. Palaeogeogr Palaeoclimatol Palaeoecol 156:177-193

Grant WS, Bowen BW (1998) Shallow population histories in deep evolutionary lineages of marine fishes: insights from sardine and anchovies and lessons for conservation. J Hered 89:415-426

Guindon S, Gascuel O (2003) A simple, fast, and accurate algorithm to estimate large phylogenies by maximum likelihood. Syst Biol 52:696-704

Harada S, Jeon SR, Kinoshita I, Tanaka M, Nishida M (2002) Phylogenetic relationships of four species of floating gobies (Gymnogobius) as inferred from partial mitochondrial cytochrome $b$ gene sequences. Ichthyol Res 49: 324-332

> Hewitt GM (1999) Post-glacial re-colonization of European biota. Biol J Linn Soc Lond 68:87-112

Hewitt GM (2001) Speciation, hybrid zones and phylogeography - or seeing genes in space and time. Mol Ecol 10:537-549

Hewitt GM (2004) Genetic consequences of climatic oscillations in the Quaternary. Philos Trans R Soc Lond B 359: 183-195

Hirase S, Ikeda M, Kanno M, Kijima A (2012) Detection of regional allozyme divergence in the rocky intertidal goby Chanogobius annularis. Ichthyol Res (in press)

> Hoarau G, Coyer JA, Veldsink JH, Stam WT, Olsen JL (2007) Glacial refugia and recolonization pathways in the brown seaweed Fucus serratus. Mol Ecol 16:3606-3616

> Ikeda H, Setoguchi H (2006) Phylogeography of Arcterica nana (Ericaceae) suggests another range expansion history of Japanese alpine plants. J Plant Res 119:489-495

Kaizuka S, Naruse H, Ohta Y, Koike K (1995) Nature of Japan 4: plains and coasts of Japan. New Ed, Iwanami-
Shoten, Tokyo (in Japanese)

Katayama S, Watanabe S, Fukuda M (2008) The production structure of demersal fish assemblages in sandy shallow areas of Sagami Bay. Nippon Suisan Gakkaishi 74:36-44 (in Japanese)

Kitamura A (2010) Nihonrettou no Seiritsu to Kokankyo. In: Watanabe K, Takahashi $\mathrm{H}$ (ed) Tanshuigyoruichiri no Shizenshi. Hokkaido University Press, Hokkaido, p $13-28$

Kitamura A, Kimoto K (2006) History of the inflow of the warm Tsushima Current into the Sea of Japan between 3.5 and 0.8 Ma. Palaeogeogr Palaeoclimatol Palaeoecol 236:355-366

Kitamura A, Takano O, Takata H, Omote H (2001) Late Pliocene-early Pleistocene paleoceanographic evolution of Sea of Japan. Palaeogeogr Palaeoclimatol Palaeoecol 172:81-98

Kojima S, Segawa R, Hayashi I (1997) Genetic differentiation among populations of the Japanese turban shell Turbo (Batillus) cornutus corresponding to warm currents. Mar Ecol Prog Ser 150:149-155

> Kojima S, Hayashi I, Kim D, Iijima A, Furota T (2004) Phylogeography of an intertidal direct-developing gastropod Batillaria cumingi around the Japanese Islands. Mar Ecol Prog Ser 276:161-172

Kokita T, Nohara K (2011) Phylogeography and historical demography of the anadromous fish Leucopsarion petersii in relation to geological history and oceanography around the Japanese Archipelago. Mol Ecol 20:143-164

Kukla G (2005) Saalian supercycle, Mindel/Riss interglacial and Milankovitch's dating. Quat Sci Rev 24:1573-1583

Lamb T, Avise JC (1986) Directional introgression of mitochondrial DNA in a hybrid population of tree frogs: the influence of mating behavior. Proc Natl Acad Sci USA 83: 2526-2530

Maggs CA, Castilho R, Foltz D, Henzler C and others (2008) Evaluating signatures of glacial refugia for North Atlantic benthic marine taxa. Ecology 89:S108-S122

Matsuura K, Shinohara G (2006) Natural history of the Japanese Islands. Tokai University Press, Tokyo (in Japanese)

Matsuyama M, Ohta S, Hibiya T, Yamada H (1993) Strong tidal currents observed near the bottom in the Suruga Trough, central Japan. J Oceanogr 49:683-696

Nakamura S (1936) Larvae and young of fishes found in the vicinity of Kominato, II-VI. J Imp Fish Inst 31:131-166

Niimura $Y$, Irino $T$, Oba $T$ (2006) Paleoenvironmental change off Kashima, central Japan, during the last 144000 years based on the planktonic foraminiferal assemblage. Fossils (Tokyo) 79:4-17 (in Japanese)

> Oba T, Kato M, Kitazato H (1991) Paleoenvironmental changes in the Japan Sea during the last 85000 years. Paleoceanography 6:499-518

Orti G, Bell MA, Reimchen TE, Meyer A (1994) Global survey of mitochondrial DNA sequences in the threespine stickleback: evidence for recent migrations. Evolution 48:608-622

Pearson RG (2006) Climate change and the migration capacity of species. Trends Ecol Evol 21:111-113

- Pearson RG, Dawson TP (2003) Predicting the impacts of climate change on the distribution of species: Are bioclimate envelope models useful? Glob Ecol Biogeogr 12: 361-371

Posada D, Crandall KA (1998) Modeltest: testing the model of DNA substitution. Bioinformatics 14:817-818 
Provan J, Bennett KD (2008) Phylogeographic insights into cryptic glacial refugia. Trends Ecol Evol 23:564-571

> Provan J, Wattier RA, Maggs CA (2005) Phylogeographic analysis of the red seaweed Palmaria palmata reveals a Pleistocene marine glacial refugium in the English Channel. Mol Ecol 14:793-803

Rogers AR, Harpending H (1992) Population growth makes waves in the distribution of pairwise genetic differences. Mol Biol Evol 9:552-569

Rosenberg NA, Feldman MW (2002) The relationship between coalescence times and population divergence times. In: Slatkin M, Veuille M (eds) Modern developments in theoretical population genetics. Oxford University Press, New York, NY, p 130-164

Sasaki T, Hattori J (1969) Comparative ecology of two closely related sympatric gobiid fishes living in tide pools. Jpn J Ichthyol 15:143-155

Sota T, Mukai T, Shinozaki T, Sato H, Yodoe K (2005) Genetic differentiation of the gobies Gymnogobius castaneus and G. taranetzi in the region surrounding the Sea of Japan as inferred from a mitochondrial gene genealogy. Zool Sci (Tokyo) 22:87-93

Swofford DL (2002) PAUP*: phylogenetic analysis using parsimony ("and other methods), version 4.0b10. Sinauer Associates, Sunderland, MA

Taberlet P, Fumagalli L, Wust-Saucy AG, Cosson JF (1998) Comparative phylogeography and postglacial colonization routes in Europe. Mol Ecol 7:453-464

Tada R (1994) Paleoceanographic evolution of the Japan Sea. Palaeogeogr Palaeoclimatol Palaeoecol 108:487-508

Tada R, Irino T, Koizumi I (1999) Land-ocean linkages over

Editorial responsibility: John Choat,

Townsville, Queensland, Australia orbital and millennial timescales recorded in late Quaternary sediments of the Japan Sea. Paleoceanography 14: 236-247

> Tajima F (1989) Statistical method for testing the neutral mutation hypothesis by DNA polymorphism. Genetics 123:585-595

Takezaki N, Rzhetsky A, Nei M (1995) Phylogenetic test of the molecular clock and linearized trees. Mol Biol Evol 12:823-833

Thompson JD, Higgins DG, Gibson TJ (1994) CLUSTAL W: improving the sensitivity of progressive multiple sequence alignment through sequence weighting, position-specific gap penalties and weight matrix choice. Nucleic Acids Res 22:4673-4680

Tringali MD, Bert TM, Seyoum S, Bermingham E, Bartolacci D (1999) Molecular phylogenetics and ecological diversification of the transisthmian fish genus Centropomus (Perciformes: Centropomidae). Mol Phylogenet Evol 13: 193-207

> Watanabe K, Mori S, Nishida M (2003) Genetic relationships and origin of two geographic groups of the freshwater threespine stickleback, 'Hariyo'. Zool Sci (Tokyo) 20: 265-274

Williams M, Dunkerley D, De Dekker P, Kershaw P, Chappell M (1998) Quaternary environments. Arnold, London

Yagishita N, Nakabo T (2003) Evolutionary trend in feeding habits of Girella (Perciformes: Girellidae). Ichthyol Res 50:358-366

Zhang Y, Ryder OA (1995) Different rates of mitochondrial DNA sequence evolution in Kirk's dik-dik (Madoqua kirkii) populations. Mol Phylogenet Evol 4:291-297

Submitted: June 15, 2011; Accepted: January 5, 2012

Proofs received from author(s): March 18, 2012 